\title{
Serum Kynurenine in Rheumatoid Arthritis
}

\author{
Harry Spiera and Ramon Vallarino \\ From the Department of Medicine, Mount Sinai School of Medicine of The City \\ University of New York, New York 10029
}

\begin{abstract}
A в S T R A C T The concentration of kynurenine has been measured in the serum of patients with rheumatoid arthritis and in a control group. The mean serum concentration was $2.27 \pm 0.688 \mu \mathrm{g} / \mathrm{ml}$ for patients with rheumatoid arthritis and $2.95 \pm 0.825 \mu \mathrm{g} / \mathrm{ml}$ for the control group.

Kynurenine: creatinine clearance ratios were higher in the rheumatoid arthritis than in the control group. These data suggest that the increased urinary excretion of kynurenine by patients with rheumatoid arthritis is due at least in part to renal factors.
\end{abstract}

\section{INTRODUCTION}

Most patients with rheumatoid arthritis excrete in their urine increased quantities of metabolic products of tryptophan (1-6). The products most consistently found in abnormal quantities are kynurenine, 3-hydroxyanthranilic acid, hydroxykynurenine, and xanthurenic acid. These are all of the kynurenine pathway of tryptophan metabolism. Products of the serotonin pathway are excreted in normal quantities. On this basis it was postulated that patients with rheumatoid arthritis had increased hepatic tryptophan pyrrolase activity resulting in a shunt of tryptophan into the kynurenine pathway (7). Subsequently, studies performed on liver biopsy specimens obtained from patients with rheumatoid arthritis demonstrated increased tryptophan pyrrolase activity in those patients with increased kynurenine excretion (8). The number of patients studied in this fashion was small, but the results seemed to verify the hypothesis offered to explain the abnormality of tryptophan metabolism manifested by patients with rheumatoid arthritis.

An alternate possibility, that the increased excretion could be due to renal rather than metabolic factors, could not heretofore be tested for lack of suitable techniques for the measurement of these metabolites in serum. We have been able to adapt Thompsett's (9) method for

\footnotetext{
Received for publication 17 September 1968 and in revised form 15 January 1969.
}

measurement of kynurenine in urine to its measurement in serum by using an absorption cell with a long light path. Using this method we have studied the serum kynurenine concentration in a group of patients with rheumatoid arthritis and in a control group. We have also studied kynurenine: creatinine clearance ratios in these two groups. These studies form the basis of this report.

\section{METHODS}

Patients were from the clinics and wards of The Mount Sinai Hospital. Patients with rheumatoid arthritis met the criteria for definite or classical rheumatoid arthritis as defined in the American Rheumatism Association criteria (10). Control patients were healthy employees.

Bloods were drawn in the fasting state and the sera separated and frozen till they were analyzed. Urines were collected in the morning after the initial specimen had been discarded. No drugs or food were allowed till after the urine collection; water intake was encouraged.

Urine kynurenine was determined by the method of Thompsett (9). Serum and urine creatinine were measured with a Technicon AutoAnalyzer by standard methods (11). For studies of clearance ratios the patients were instructed to empty their bladder on arising and consume $250 \mathrm{cc}$ of water. $1 \mathrm{hr}$ later blood was drawn, and $2 \mathrm{hr}$ later the bladder was emptied. Clearance ratios were calculated by the formula: $\mathrm{R}=\mathrm{C}_{\mathrm{kyn}} / \mathrm{C}_{\mathrm{cre}}=\mathrm{U}_{\mathrm{kyn}} \times \mathrm{P}_{\text {cre }} / \mathrm{U}_{\text {cre }} \times \mathrm{P}_{\mathrm{kyn} \text {. }}$

Serum kynurenine was determined as follows:

Serum kynurenine. Into a $45 \mathrm{ml}$ plastic centrifuge add $8.0 \mathrm{ml}$ of serum and dilute to $10 \mathrm{ml}$ with distilled water, add $10 \mathrm{ml}$ of $20 \%$ trichloroacetic acid, stir with two round applicators, wait $5 \mathrm{~min}$, stir again, and centrifuge for $5 \mathrm{~min}$. The supernatant is transferred to a $25 \mathrm{ml}$ graduated cylinder, and the volume is recorded. It is then transferred to a $120 \mathrm{ml}$ sidearm distilling flask and diluted to $40 \mathrm{ml}$ with distilled water. To the above, $10 \mathrm{ml}$ of saturated sodium hydroxide is added. Three boiling chips and a tuft of Pyrex glass wool are placed into the flask. Two additional glass tufts are added in the neck of the distilling flask, one at the base of the neck above the bulb, the other just below the side arm. The flask is stoppered with a No. 3 rubber stopper and mounted in a fluidized sand bath ${ }^{1}$ and distilled at $125^{\circ} \mathrm{C}$. The distillate passes through a $7 \frac{3}{4}$ inch condenser and col-

${ }^{1}$ Tecam fluidized bath, Type SBC Techne (Cambridge) Ltd., Duxford, Cambridge, England. 
lected in a $25 \mathrm{ml}$ Erlenmeyer flask, and the first $20 \mathrm{ml}$ is collected.

The above $20 \mathrm{ml}$ of distillate is transferred to a $50 \mathrm{ml}$ Erlenmeyer flask to which are added $0.4 \mathrm{ml}$ of $10 \mathrm{~N} \mathrm{HCl}+2$ $\mathrm{ml}$ of $0.1 \%$ sodium nitrite; wait $5 \mathrm{~min}$, add $2 \mathrm{ml}$ of $0.5 \%$ ammonium sulfamate; wait $5 \mathrm{~min}$ and add $2 \mathrm{ml}$ of Marshall reagent. (Note flask must be stirred after each of the preceding reagents are added.). After $3 \frac{1}{2} \mathrm{hr}$ read in Beckman spectrophotometer at $540 \lambda$, with a $100 \mathrm{~mm}$ Vycor cylindrical cell (Corning Glass Works, Corning, N. Y.) reading optical density.

Only four samples are developed at one time, as there is a long reading time. The blank is $20 \mathrm{ml}$ of distilled water treated as deproteinized serum.

The standard curve is prepared by adding known quantities of kynurenine to serum aliquots. The standard curve must be made up with plasma or serum.

\section{RESULTS}

Table I shows the recovery of known amounts of kynurenine added to serum. It can be seen that recovery is 81$109 \%$. Aspirin, propoxyphene, prednisone, and mycochrysine when added to serum did not interfere with the determination. Two patients with psoriasis who were serving as controls were studied three times a week for a period of $4 \mathrm{wk}$, and the serum kynurenine remained constant within $15 \%$. Changes in serum kynurenine concentration after meals were variable, sometimes rising and sometimes falling; therefore, only fasting specimens were used for the study.

Tables II and III show serum kynurenine concentrations, serum creatinine concentration, urinary excretion of kynurenine per milligram of creatinine, and clearance ratio of kynurenine to creatinine. Serum kynurenine concentration was $2.27 \pm(\mathrm{SD}) 0.825 \mu \mathrm{g} / \mathrm{ml}$ for patients with

TABLE I

Recovery of Kynurenine Added to Serum*

\begin{tabular}{cccc}
\hline Added & Recovered & Recovered & $\begin{array}{c}\text { Final con- } \\
\text { centration }\end{array}$ \\
\hline$\mu g / m l$ & $\mu g / m l$ & $\%$ & $\mu g / m l$ \\
0.25 & 0.24 & 97 & $1.09 \ddagger$ \\
0.50 & 0.54 & 109 & $1.39 \ddagger$ \\
0.75 & 0.71 & 94 & $1.56 \ddagger$ \\
1.00 & 0.88 & 88 & $1.73 \ddagger$ \\
1.25 & 1.01 & 81 & $1.98 \S$ \\
1.50 & 1.52 & 100 & $2.49 \S$ \\
2.00 & 1.82 & 91 & $2.79 \S$ \\
2.50 & 2.22 & 89 & $3.19 \S$ \\
3.00 & 2.66 & 89 & $3.63 \S$
\end{tabular}

* Results of two experiments using different sera over the following ranges: $0.25-1.00 \mu \mathrm{g} / \mathrm{ml}$ and $1.25-3.00 \mu \mathrm{g} / \mathrm{ml}$. The above values are the means of three determinations.

† Serum kynurenine concentration without added kynurenine: $0.85 \mu \mathrm{g} / \mathrm{ml}$.

\$ Serum kynurenine concentration without added kynurenine: $0.97 \mu \mathrm{g} / \mathrm{ml}$.
TABLE II

Rheumatoid Arthritis Group

\begin{tabular}{|c|c|c|c|c|}
\hline \multirow[b]{2}{*}{ Patient } & \multirow[b]{2}{*}{$\underset{\text { kynurenine }}{\text { Serum }}$} & \multirow[b]{2}{*}{$\begin{array}{c}\text { Serum } \\
\text { creatinine }\end{array}$} & Urinary excretion & \multirow[b]{2}{*}{$R \times 10^{4 *}$} \\
\hline & & & $\frac{\mathrm{mg} \text { kynurenine }}{\mathrm{mg} \text { creatinine }} \times 10^{\mathrm{b}}$ & \\
\hline & $\mu g / m l$ & $\mathrm{mg} / 100 \mathrm{ml}$ & & \\
\hline S. H. & 1.95 & 0.572 & 474 & 139 \\
\hline M. E. & 1.63 & 1.080 & & \\
\hline S. L. & 1.73 & 1.120 & & \\
\hline W. S. & 2.46 & 0.936 & & \\
\hline P. F. & 2.96 & 0.789 & 161 & 42 \\
\hline D. T. & 2.91 & 0.672 & 668 & 48 \\
\hline J. S. & 3.45 & 0.648 & 260 & 154 \\
\hline F. S. & 1.66 & 1.120 & & \\
\hline D. V. & 1.49 & 0.440 & 1324 & 390 \\
\hline M. T. & 2.19 & 0.584 & 2895 & 772 \\
\hline B. G. & 1.97 & 0.664 & 702 & 236 \\
\hline B. S. & 1.23 & 0.544 & 408 & 180 \\
\hline F. G. & 1.36 & 0.744 & 1162 & 635 \\
\hline W. W. & 3.61 & 0.880 & 343 & 83 \\
\hline $\mathbf{M}$ & 2.32 & 0.880 & 198 & 75 \\
\hline E. S. & 1.62 & 0.592 & 353 & 129 \\
\hline H. S. & 3.47 & 0.800 & 673 & 155 \\
\hline M. C. & 1.59 & 0.496 & 360 & 112 \\
\hline I. C. & 2.42 & 0.560 & 1142 & 264 \\
\hline S. D. & 3.36 & 0.960 & 149 & 42 \\
\hline
\end{tabular}

* Urinary kynurenine $X$ serum creatinine

urinary creatinine $X$ serum kynurenine

rheumatoid arthritis, and $2.95 \pm 0.825 \mu \mathrm{g} / \mathrm{ml}$ in the control group. The difference is statistically significant $(P$ $<0.005) .^{2}$ The rheumatoid arthritis group excreted $0.00705 \pm$ (SD) $0.00691 \mathrm{mg}$ of kynurenine per $\mathrm{mg}$ of creatinine, while the control group excreted $0.00178 \pm$ (SD) $0.00190 \mathrm{mg}$ of kynurenine per $\mathrm{mg}$ of creatinine. The difference is also significant $(P<0.01)$. The clearance ratio of kynurenine to creatinine was $0.0216 \pm$ (sD) 0.0212 in the rheumatoid arthritis group as compared to $0.0048 \pm$ (SD) 0.0046 in the control group. The difference is significant $(P<0.01)$. Serum creatinine concentrations were similar in both groups.

\section{DISCUSSION}

The data clearly demonstrate that the serum concentration of kynurenine is low in approximately $50 \%$ of patients with rheumatoid arthritis. The combined urine and serum data show a considerably increased renal clearance of kynurenine by patients with rheumatoid arthritis. It is therefore quite evident that renal factors play an important role in the increased urinary excretion of kynurenine by these patients. On the basis of earlier find-

\footnotetext{
${ }^{2}$ The probabilities are based on Behren's modification of the Student's $t$ test as used when the variances are significantly unequal.
} 
TABLE III

Control

\begin{tabular}{|c|c|c|c|c|}
\hline \multirow[b]{2}{*}{ Patient } & \multirow[b]{2}{*}{$\begin{array}{c}\text { Serum } \\
\text { kynurenine }\end{array}$} & \multirow[b]{2}{*}{$\begin{array}{l}\text { Serum } \\
\text { creatinine }\end{array}$} & Urinary excretion & \multirow[b]{2}{*}{$\mathrm{R} \times 10^{4 *}$} \\
\hline & & & $\frac{\mathrm{mg} \text { kynurenine }}{\mathrm{mg} \text { creatinine }} \times 10^{5}$ & \\
\hline & $\mu g / m l$ & $m g / 100 \mathrm{ml}$ & & \\
\hline M. T. & 2.90 & 0.940 & 142 & 46 \\
\hline Z. L. & 2.45 & 0.864 & 55 & 19 \\
\hline R. V. & 3.24 & 0.920 & 104 & 29 \\
\hline C. F. & 2.95 & 0.688 & 522 & 121 \\
\hline S. S. & 2.66 & 0.912 & 125 & 42 \\
\hline L. T. & 2.60 & 0.968 & 91 & 33 \\
\hline P. O. P. & 5.48 & 0.968 & 117 & 20 \\
\hline B. J. & 2.85 & 0.800 & 230 & 64 \\
\hline M. G. & 2.54 & 0.560 & 208 & 45 \\
\hline R. M. & 2.76 & 0.672 & 1058 & 257 \\
\hline $\mathbf{N}$ & 3.06 & 0.704 & 244 & 56 \\
\hline N. J. & 2.41 & 0.848 & 104 & 36 \\
\hline P. T. & 2.62 & 0.660 & & \\
\hline S. R. & 2.61 & 0.808 & 158 & 48 \\
\hline F. F. & 3.94 & & 105 & \\
\hline K. J. & 2.59 & 0.760 & 215 & 63 \\
\hline C. A. & 3.73 & 0.968 & 143 & 37 \\
\hline J. H. & 3.35 & 1.02 & 104 & 31 \\
\hline T. A. & 2.63 & 0.776 & 141 & 41 \\
\hline B. J. & 2.51 & 1.00 & 107 & 42 \\
\hline K. A. & 2.27 & 0.696 & 158 & 48 \\
\hline W. K. & 5.82 & 0.712 & 106 & 12 \\
\hline B. B. & 3.15 & 0.840 & 101 & 26 \\
\hline H. M. & 2.70 & 0.632 & 93 & 21 \\
\hline C. M. & 2.63 & 0.840 & 89 & 28 \\
\hline G. A. & 2.36 & 0.768 & 89 & 28 \\
\hline V. G. & 2.35 & 0.672 & 227 & 64 \\
\hline B. K. & 2.48 & 0.792 & 90 & 28 \\
\hline F. M. & 3.60 & 0.864 & 133 & 31 \\
\hline B. E. & 2.34 & 0.792 & 107 & 36 \\
\hline I. F. & 2.40 & 0.720 & & \\
\hline L. P. & 2.41 & 0.504 & & \\
\hline
\end{tabular}

* Urinary kynurenine $X$ serum creatinine urinary creatinine $X$ serum kynurenine

ings from this laboratory, it was suggested that the increased excretion of the tryptophan metabolites by patients with rheumatoid arthritis was due to increased production consequent to increased tryptophan pyrrolase activity. We had previously shown that the most effective method of increasing urinary excretion of 3-hydroxyanthranilic acid in the rabbit was the administration of hydrocortisone, a potent inducer of tryptophan pyrrolase (12). Altman and Greengard (8) studied tryptophan pyrrolase activity of liver biopsy specimens. Among them were specimens obtained from patients with rheumatoid arthritis. The patients who excreted increased quantities of kynurenine had increased tryptophan pyrrolase activity. It was therefore concluded that increased tryptophan pyrrolase activity was indeed the mechanism for the abnormal tryptophan metabolism noted in patients with rheumatoid arthritis. The present study casts doubt on this view. It is possible that both renal and metabolic factors play a role. (One may speculate that due to increased renal loss of kynurenine, serum kynurenine is decreased. This loss could decrease feedback inhibition of tryptophan pyrrolase activity, and thus lead to increased tryptophan pyrrolase activity.) In vitro studies of kynurenine have been shown to inhibit tryptophan pyrrolase (13).

No information is at present available as to the serum concentration of hydroxykynurenine, xanthurenic acid, kynurenic acid, 3-hydroxyanthranilic acid, $n$-methylnicotinamide, and pyridone. Studies of renal clearance of these substances await the development of suitable methods for the determination of these substances in serum. The methods of Coppini, Benassi, and Montorsi (14) are unsuitable, as their methods are applicable only when the concentration of these substances has been increased by massive tryptophan loading. Tryptophan itself is a potent inducer of tryptophan pyrrolase (15), and therefore the test itself could result in the increased production and excretion of kynurenine.

The significance of the increased excretion of tryptophan metabolites in rheumatoid arthritis is not known. Neither the urinary excretion nor serum concentration of kynurenine seem to bear any relation to the activity of the disease, nor to any other clinical or laboratory parameter studied. Suggestion that the abnormality is related to absolute or relative pyridoxine deficiency is inadequate to explain the increased excretion of 3-hydroxyanthranilic acid. Pyridoxine is a cofactor for the enzyme kynureninase, and deficiency would result in decreased rather than increased 3-hydroxyanthranilic acid.

Steroids in large doses will induce tryptophan pyrrolase activity and thereby increase kynurenine production (8). However, the dose of steroids used in the management of rheumatoid arthritis is smaller than that necessary for the induction of enzyme. In our experience doses less than $10 \mathrm{mg}$ of prednisone per day do not influence kynurenine excretion. ${ }^{8}$

Disturbances in tryptophan metabolism have also been reported in many other diseases, including among others leukemia, Hodgkin's disease, carcinoma of the bladder, schizophrenia, and scleroderma (16). In most of the studies, the metabolic products were measured only in urine. As shown in the present investigation, it would seem that both urine and serum must be studied before any conclusion can be drawn as to the cause of the abnormality.

\footnotetext{
${ }^{8}$ Spiera, H. Unpublished observations.
} 


\section{ACKNOWLEDGMENTS}

Gratitude is expressed to the staff of the Clinical Research Center of The Mount Sinai Hospital for their kind assistance. We wish to acknowledge the technical assistance of $\mathrm{Mr}$. Seymour Perlowitz.

This investigation was supported by grant No. AM 07726 ,

National Institutes of Health, U. S. Public Health Service.

\section{REFERENCES}

1. McMillan, M. 1960. The identification of a fluorescent reducing substance in the urine of patients with rheumatoid arthritis. The excretion of 3-hydroxyanthranilic acid in this and other conditions. J. Clin. Pathol. (London). $13: 140$.

2. Bett, I. M. 1962. Metabolism of tryptophan in rheumatoid arthritis. Ann. Rheum. Dis. 21: 63.

3. Pinals, R. S. 1964. Tryptophan metabolism in rheumatic disease. Arthritis Rheum. 7: 662.

4. Beetham, W., Jr., S. Fischer, and R. Schrohenloher. 1964. Tryptophan metabolite excretion in connective tissue disease demonstrating a difference between rheumatoid spondylitis and rheumatoid arthritis. Proc. Soc. Exp. Biol. Med. 117 : 756.

5. Jaffe, I. A., and K. Altman. 1964. The effect of pyridoxine on the abnormal tryptophane metabolism in rheumatoid arthritis. Arthritis Rheum. 7: 319.

6. Flinn, J. H., J. M. Price, N. Yess, and R. R. Brown. 1964. Excretion of tryptophan metabolites by patients with rheumatoid arthritis. Arthritis Rheum. 7: 201.
7. Spiera, H. 1966. Excretion of tryptophan metabolites in rheumatoid arthritis. Arthritis Rheum. 9: 318.

8. Altman, K., and O. Greengard. 1966. Correlation of kynurenine excretion with liver tryptophan pyrrolase levels in disease and after hydrocortisone induction. J. Clin. Invest. $45: 1527$.

9. Thompsett, S. L. 1959. The determination in urine of some metabolites of tryptophan-kynurenine, anthranilic acid, and 3-hydroxyanthranilic acid-and reference to the presence of $O$-aminophenol in urine. Clin. Chim. Acta. 4: 411 .

10. Ropes, M. W., G. A. Bennett, S. Cobb, R. Jacox, and R. A. Jassar. 1958. Revision of diagnostic criteria for rheumatoid arthritis. Bull. Rheum. Dis. 9: 175.

11. Technicon AutoAnalyzer Methodology. 1963. Technicon Instrument Corporation, Chauncey, N. Y.

12. Spiera, H., and C. L. Christian. 1964. Some factors influencing urinary excretion of 3-hydroxyanthranilic acid. Proc. Soc. Exp. Biol. Med. 116: 944.

13. Wagner, C. 1964. Regulation of the tryptophan-nicotinic acid-DPN pathway in the rat. Biochem. Biophys. Res. Commun. 17: 668.

14. Coppini, D., C. A. Benassi, and M. Montorsi. 1959. Quantitative determination of tryptophan metabolites (via kynurenine) in biological fluid. Clin. Chem. 5: 391.

15. Fiegelson, P., and O. Greengard. 1962. Immunochemical evidence for increased titers of liver tryptophan pyrrolase during substrate and hormonal enzyme induction. J. Biol. Chem. 237 : 3714.

16. Musajo, L., and C. A. Benassi. 1964. Aspects of disorders of the kynurenine pathway of tryptophan metabolism in man. Advan. Clin. Chem. 7: 63. 